\title{
DOMOV INSPIRATIVNÍ I SVAZUJÍCÍ VE ŠVABINSKÉHO PORTRÉTU MIKOLÁŠE ALŠE
}

\author{
ANEŽKA MIKULCOVÁ \\ Ústav pro dějiny umění Filozofické fakulty Univerzity Karlovy + Národní památkový ústav \\ mikulcova.anezka@npu.cz
}

\begin{abstract}
Inspiring as well as binding Home in Švabinský's portrait of Mikoláš Aleš

This paper analyzes a well-known portrait of the painter Mikoláš Aleš created by Max Švabinský. The portrait could have been created thanks to the friendly connection between these artists and contains several details with a deeper meaning referring to the character of Alešs work and personality. The multi-layered perception of the topic of "home“ is particularly noticeable here.
\end{abstract}

Keywords: Mikoláš Aleš - Max Švabinský - portrait - home - home inspiring - home binding

Předložený př́íspěvek je věnován nejznámějšímu portrétu Mikoláše Alše (1852-1913), konkrétně způsobu, jakým autor tohoto portrétu Max Švabinský (1873-1962) vyjádřil vztah portrétovaného $\mathrm{k}$ široce chápanému pojmu domov. ${ }^{1}$ Budeme se tedy pohybovat na poměrně křehké interpretační půdě. Cenný zdroj informací pro analýzu portrétu tak představuje memoárová literatura, ke které je samozřejmě třeba přistupovat kriticky. Především se jedná o vzpomínky první manželky Maxe Švabinského Ely Vejrychové-Švabinské a dcery Mikoláše Alše Maryny Alšové-Svobodové. ${ }^{2}$

Mezi portrétistou a portrétovaným byl více než dvacetiletý věkový rozdíl. Maliři měli ovšem poměrně mnoho společného, oba byli např́íklad členy $\mathrm{S}$. V. U. Mánes. Mikoláš Aleš se stal jeho prvním předsedou a posléze čestným starostou. Max Švabinský byl členem spolku od roku 1892, od roku 1896 s ním začínal pravidelně vystavovat, ${ }^{3}$ v roce 1905 zastával funkci předsedy a ještě předtím byl redaktorem spolkového časopisu Paleta, jejímž horlivým přispěvatelem byl právě Aleš. ${ }^{4}$ Poprvé se osobně oba malíri potkali v roce 1896, kdy se Aleš př́išel podívat na Švabinského na Akademii, kde druhý právě pracoval

1 Text vychází z drobné kapitoly mé bakalářské práce Kult umělce na přelomu století - A. Rodin a M. Aleš podle Maxe Švabinského, psané pod vedením profesora Romana Prahla, CSc. Tuto práci jsem zatím neměla možnost veřejně prezentovat. Díky tématu konference jsem si vlastně zpětně uvědomila, $v$ jaké další rovině je možné na Alšův portrét nahlížet.

2 Ela Švabinská, Vzpomínky z mládí, Praha 1960; Maryna Alšová-Svobodová, U nás doma, Praha 1970.

3 Zuzana Švabinská - Václav Ševčík - Martin Kuna, Max Švabinský. Soupis kresliřského a malírského díla 1879-1916, Kroměříž 2014, s. 317.

4 Jindřich Bořecký (ed.) - Lucie Gočárová (ed.) - Václav Špale (ed.), Spolek výtvarných umělců Mánes 1887-2007, Praha 2007, s. 7. 
na Splynutí duši ${ }^{5} \mathrm{Z}$ celé generace českých mladých umělců byl snad právě Max Švabinský Alšovým největším obdivovatelem. Jeho vřelé sympatie k Alšově osobě a tvorbě byly zřejmě dobře patrné už při letmé zmínce Alšova jména, jak dokládá na několika místech svých pamětí Švabinského první osudová žena Ela Vejrychová, později Švabinská. O zcela prvním setkání s Maxem tak později napsala: „Mluvil o umění, o malírství a se zvláštní láskou a úctou o svém profesoru Maxu Pirnerovi, líbila se mu poetická něha jeho figur a básnická fantasie. Obdivoval profesora Vojtěcha Hynaise (...). Celý se však změnil, mluvil-li o Alšovi. Objasňoval nám, že on dovedl ve svých kresbách vystihnout duši českého lidu, mluvil o nádherné kráse, o hudbě linií a mohutné komposici a zvláště o heroickém obsahu jeho lunet..." 6 Především pak byl prý Mikoláš Aleš jeden z mála uměleckých kolegů, kterého Švabinský několikrát navštívil k večernímu pohovoru. ${ }^{7}$

Výsledkem těchto návštěv byl portrét $\mathrm{z}$ roku 1908 s věnováním v dolním levém rohu „Mistru Mikoláši Alšovi MŠvabinský březen 1908.“ Jde o nejslavnější portrét Mikoláše Alše. Lze říci, že naprosté většině lidí při vyslovení Alšova jména vytane na mysli vedle jeho kreseb právě tato podobizna [1]. Max Švabinský se tak silně podílel na vytvoření Alšovy image. Alšova podobizna byla vydána spolu s dalšími 99 portréty významných osobností české kultury v knize Švabinského český Slavín. ${ }^{8}$ Patří do méně početné skupiny podobizen od Švabinského, které zachycují konkrétní prostředí, kde obraz vznikal. ${ }^{9}$ Vidíme zde Mikoláše Alše sedícího ve své pracovně u svého stolu, na němž leží list papíru $s$ kresbou, kalamář a pero. V pozadí lze rozeznat dveře a na stěně visící dva obrázky. Nešlo o nějakou stylizaci, Švabinský skutečně přišel za portrétovaným do jeho bytu, konkrétně podobizna vznikala v Alšově pracovně u stolu šimlíčku. ${ }^{10}$ Ke konci života ostatně Švabinský označil jednu ze skic k Alšovu portrétu takto: „Aleš od Švabinského, pravý. Varianta $z$ doby, kdy jsem kreslil Aleše dle skutečnosti. MŠvabinský 2. X. 1960."11 Alšova rodina v té době žila v nájemním domě na Vinohradech v tehdejší Havlíčkově ulici čp. 1018. Do vinohradského bytu chodil na návštěvy i Karel Václav Rais, pro něhož Aleš vytvořil řadu ilustrací. Spisovatel vzpomínal na Alšovu pracovnu následovně: „Sedávali jsme proti sobě $v$ tom jeho pokojíku tichém a skromném, jehož hlavním bohatstvím byly skřině s knihami a trocha rodinných a př́telských památek, u prostého stolečku, na němž provedl většinu svých prací."12 Skutečnost, že Max Švabinský portrétovaného navštívil u něj doma, není zas tak něco neobvyklého, např́klad portrét Antonína Dvořáka vznikal také ve skladatelově domě. V Alšově př́ípadě to však bylo dáno nejen tím, že jej Max Švabinský rád navštěvoval, ale také tím, že přibližně posledních deset let Mikoláš Aleš i několik měsíců nevycházel ze svého bytu. ${ }^{13}$ Pro Alše se tak v pokročilejším věku stal domov, coby místo žití, do jisté míry domovem svazujícím.

5 Ludvík Páleníček, Max Švabinský. Život a dílo na přelomu epoch, Praha 1984, s. 231.

6 Ela Švabinská, Vzpomínky z mládí, Praha 1960, s. 101.

7 Ibidem, s. 288.

8 Ludvík Páleníček, Švabinského český Slavín, Praha 1973. Portréty vybral a uspořádal Ludvík Páleníček.

9 Takovýto postup zvolil Švabinský ještě při portrétování např́klad Jana Štursy, který je zobrazen mezi sochařskými pomi̊ckami, či archeologa, antropologa a slavisty Lubora Niederleho obklopeného drobnými soškami, nalezenými nádobami či lupou.

10 Maryna Alšová-Svobodová, U nás doma, Praha 1970, s. 67.

11 Švabinská - Ševčík - Kuna (pozn. 3), s. 239.

12 Karel Václav Rais, Ze vzpomínek II, Praha 1927, s. 248.

13 Emanuel Svoboda, Jak Mikoláš Aleš žil a tvořil, Praha 1920, s. 143, nebo také Karel Špillar, Drobné vzpomínky na Mikuláše Aleše II, Český svět XXIV, 1928, s. 7. 
Jestliže je jisté, že podobizna byla malována v Alšově vinohradské pracovně, můžeme ji porovnat $\mathrm{s}$ fotografií Mikoláše Alše v pracovně z roku 1912, ${ }^{14} \mathrm{~s}$ fotografickým záběrem na samotnou Alšovu pracovnu $\mathrm{z}$ roku 1913 a dále s mobiliářem naznačeným na modelu Alšovy pracovny zveřejněném $\mathrm{v}$ katalogu umělcovy výstavy z roku 2007, který vychází z pozůstalosti Mikoláše Alše uložené v Památníku národního písemnictví [2]. ${ }^{15}$ Světlo dopadající na malířovu postavu zleva a dveře v pozadí rovněž odpovídají uspořádání v pracovně. Mikoláš Aleš nekontaktuje diváka pohledem, nýbrž se dívá se zájmem oknem ven, a právě pozorování života venku na přilehlém prostranství bylo v pozdějším období malírova života jeho častou zálibou. Leckdy tak nacházel inspiraci pro své kresby, jako v př́padě perokresby $Z a$ chlebem $\mathrm{z}$ roku 1909 vzniklé bezprostředně poté, co viděl chudou rodinu přicházející do Prahy. ${ }^{16}$ Domov tak pro něj nebyl pouze domovem svazujícím, ale i domovem inspirujícím.

Dva obrázky visící za Mikolášem Alšem na stěně neodpovídají svému umístění v reálu, což dokazuje, že jejich výběr a umístění na pozadí Alšova portrétu nebyl náhodný. První z nich představuje bud'kreslený obraz motýlů, nebo pravděpodobněji prosklené tabló se skutečným přišpendleným hmyzem. ${ }^{17}$ Právě motýli byli dalším společným zájmem obou malírư a představovali téma rozhovorů během jejich společných sezení i během samotného vzniku portrétu. Oba umělci znali i leckterá latinská jména motýlů a často je zobrazovali na svých malbách a kresbách. ${ }^{18}$ Alšova dcera také vzpomíná, jak přinesl tatínek domů housenky otakárků, z nichž se pak úspěšně vylíhli motýli, či v jaké oblibě měl maliř lampu, kterou jeho dcera pomalovala motýly. ${ }^{19}$ Př̀ své návštěvě u Alšových namaloval Švabinský také přátelskou karikaturu Mikoláše Alše, k níž Aleš přikreslil kuklu motýla [3].

Obrázek nalevo od motýlů představuje podobiznu Alšovy maminky Veroniky, rozené Fanfulové, z roku 1864, autorem byl Jan Aleš, starší bratr Mikoláše [4]. Byl o čtyři roky starší než Mikoláš a svými zájmy o přírodu a kreslení měl do značné míry vliv na svého mladšího bratra. Během Janových gymnaziálních studií vznikly mnohé kresby přírody i historických výjevů, jimiž se i v pozdějším věku Mikoláš Aleš inspiroval a sám svého bratra označil za svého „prvního a snad nejvlivnéjšího učitele kresleni“. ${ }^{20}$ Ve svých devatenácti letech zemřel za ne zcela jasných okolností, což mladého Mikoláše hluboce zasáhlo. Mikoláš Aleš po celý život uchovával bratrovy kresby. V jeho vinohradském bytě byly umístěny jak Janovy kresby motýlů, tak jeho kreslený portrét maminky. Obě kresby Švabinského velmi zaujaly, portrét dokonce připodobnil k tvorbě Hanse Holbeina. ${ }^{21}$ Paní

14 Tři fotografie umělce sedícího za psacím stolem jsou uloženy v osobním fondu umělce v archivu Národní galerie v Praze, č. fondu 21, inv. č. 49.

15 Ondřej Chrobák (ed.), Mikoláš Aleš 1852-2007 (katalog výstavy), Praha 2007, nepag.

16 Mikoláš Aleš (et al.), M. Aleš mládeži, Praha 1957, s. 349.

17 Takovouto ukázku z Alšovy sbírky motýlů lze vidět na fotografii Mikoláš Aleš v pracovně (1912) a lze ji ztotožnit s papírovou krabicí se skleněným víkem se 47 kusy domácích i exotických motýlů a brouků, jak je vedena v pozůstalosti v Památníku národního písemnictví.

18 Ještě více se obliba a dobrá znalost motýlů, a to nejen domácích, ale i exotických, promítá do díla Maxe Švabinského. Jeho četné kresby a drobné malby motýlů daly vzniknout půvabnému svazku Motýlí čas, doprovázenému verši Františka Hrubína. S třemi motýly se setkáme i na pozadí obrazu Kamélie, portrétu Ely Švabinské z roku 1903. Namalované skleněné tabló s přišpendlenými motýly je i na obraze Ateliér (1916), jenž měl pro Švabinského hluboký osobní obsah.

19 Alšová-Svobodová (pozn. 10), s. 31 a s. 60.

20 Aleš (et al.) (pozn. 16), s. 344. Citace z doslovu od E. Svobody.

21 Alšová-Svobodová (pozn. 10), s. 68. 
Alšová vyšívala lidové ornamenty podle svých vlastních návrhů a při práci svým dětem zpívala lidové písně a vyprávěla pohádky, ${ }^{22}$ což se jistě projevilo v Mikolášově tvorbě. S lidovým čepcem, v němž je paní Alšová zobrazena, se dobře doplňuje i vyřezávaný rám s lidovými motivy, který byl darem od Alšova prrítele malíre Jana Prouska. ${ }^{23}$ Sám Aleš vycházel v roce 1889 z bratrova zachycení podoby jejich matky při tvorbě kresby Ach mámo, mamičko! z cyklu Sirotek, což dosvědčuje, jak velký význam pro něj bratrova kresba měla. Její portrét vytvořený milovaným bratrem představoval pro Alše dvojitou vzpomínku na obě milované osoby, na jeho dětství, a zosobňoval Alšův domov jako rodinné zázemí. Je třeba říci, že obrázek byl ve skutečnosti umístěn nad malířovou postelí. ${ }^{24}$ Max Švabinský tak - pravděpodobně na základě Alšova přání - druhotně zakomponoval do Alšova portrétu jeho bratra i matku.

To odpovídá Švabinského snaze zachytit portrétované s jejich blízkými, v případě Alše to navíc koresponduje s jeho velkým zájmem o své předky. Ten se projevil při zkoumání genealogie jeho rodu, potažmo v celkovém zájmu o českou historii a heraldiku. ${ }^{25}$ Řada Alšových současníků i mladších kolegů vyzdvihovala ryzí češství Alšovy tvorby i osoby. K jeho vlasteneckému vystupování patřilo nošení čamary, zájem o lidové písně, kroje, české dějiny, erby staré zemské šlechty, zájem o historii vlastního rodu, různé výlety, které podnikal po české vlasti - především po starých královských městech, hradech a zámcích - a dokonce i jeho slovní projev. Karel Mašek např́iklad vzpomínal, jak Aleš hovořil zajímavým slohem osvojeným z kronik a Bible. ${ }^{26}$ Pro Alše bylo tedy nesmírně důležité a inspirující vnímání domova jako domoviny, národa a českých zemí. Švabinský se pravděpodobně snažil vyjádřit tento Alšův vztah k historii nejen prostřednictvím portrétu paní Alšové, ale také prostřednictvím rozpracované kresby, kterou má Aleš před sebou. S jistou dávkou opatrnosti v něm lze vyčíst rozpaženého bojovníka jedoucího na koni a srovnatelného s řadou jezdců na koních, at už husitů, uherských jezdců, či hulánů, se kterými se často setkáváme v Alšově tvorbě. Na tomto místě zmiňme zajímavou spojitost mezi Alšovými kresbami husarů a Švabinského návrhem k plakátu Vzpomeňte svých bratří v poli (1914), v němž Švabinský stylizací kresby i písma nápadně odkazuje na tvorbu svého staršího kolegy.

Max Švabinský prý nikdy neurčoval pózu, kterou měl portrétovaný zaujmout, takže veškerá natočení hlavy, posazení a poloha rukou by měly být zachyceny tak, jak byly malovanému nejpřirozenější. Sám malír se nechal slyšet, že mu jde o to, aby byl na podobizně rozpoznatelný nejen model, ale i jeho předci a všechny znaky jeho osobnosti, individuální zvláštnosti a psychika. ${ }^{27}$ Co se týče podoby samotného Mikoláše Alše, kterému bylo v době portrétování padesát šest let, jsou zde zachyceny všechny rysy typické pro jeho osobu. Oblečení je v porovnání s jinými oficiálními podobiznami z rukou Maxe Švabinského ležérnější a vyhovující pohodlí portrétovaného. Zatímco malířova pravá

${ }^{22}$ Kontakt Mikoláše Alše s národními tradicemi a lidovou kulturou je popsán mj. Emanuelem Svobodou v úvodu knihy Špaliček národních písní a říkadel.

23 Alšová-Svobodová (pozn. 10), s. 111.

${ }^{24}$ Jak dokládá fotografie z roku 1913, lze se domnívat, že na tomto místě obrázek visel již v roce 1908. Také K. V. Rais v knize Ze vzpomínek II uvádí, že kresba visela nad malírovou postelí.

25 V Alšově knihovně se např́klad nacházela kniha Práwa městská království Czieského z roku 1579, viz http://www.osobniknihovny.cz/detail.do?articleId=8674 [citováno 15. 5. 2018].

${ }^{26}$ Karel Mašek, Tři léta s „Mánesem“. K dějinnému vývoji výtvarného umění, Praha 1922, s. 34.

27 Páleníček (pozn. 8), s. 12. 
ruka je v klidu, levá ruka blíž k oknu je sevřená a položená na madlech židle. Výraz malírových očí ukazuje živý zájem o věci odehrávající se za oknem pokoje a prozrazují jeho psychickou aktivitu, jako by právě objevil nový námět další práce, k níž je na stole již vše připraveno. Svižně načrtnutá kresba před Alšem patrně ilustruje živelnost jeho tvorby, která se vymykala zaběhlým akademickým finesám. Alšova mysl je tedy vábena směrem z bytu, ale jeho fyzická schránka je naopak „zakotvena“ uvnitř pracovny, což ještě podtrhuje na první pohled zřejmé sesunutí těla k pravé straně. Nápadné naklonění horní poloviny těla na jednu stranu je zaznamenatelné na více podobiznách z pozdějšího období Alšova života, např́klad na fotografii z roku 1912 z malírovy poslední cesty do rodných Mirotic, či ještě lépe na bustě od Bohumila Kafky z roku 1902. ${ }^{28}$ Je tedy opravdu možné, že toto držení těla bylo vyvoláno nějakými zdravotními obtížemi, ${ }^{29}$ jimž by odpovídala i zmíněná skutečnost, že Aleš ze svého bytu již př́iliš nevycházel. Na kresbě by tak byl zachycen rozpor mezi tělesnem, působícím Alšovi jistě určité potíže při práci, a mezi duchovnem, jeho neustále hravou myslí plnou nápadi̊.

Rodina Mikoláše Alše si portrétu od Maxe Švabinského velmi vážila. Až dojemně působí dopisy od paní Maryny Alšové adresované Švabinskému, kdy po mnoha letech od vzniku portrétu nikdy nezapomene poděkovat za zmiňovaný portrét. ${ }^{30}$ Podle podobizny byla vytvořena prémie spolku Mánes na rok 1909, ${ }^{31}$ podobizna byla rovněž reprodukována ve Volných směrech roku 1908 či v textu o Alšovi z edice Zlatoroh roku 1912.

Skutečnost, že právě takovýto typ ležérněji pojatého portrétu se zamlouval i samotnému Alšovi, dokazuje i další Švabinského portrét Mikoláše Alše. Jde o kresbu tuší z roku 1908 zachycující uvolněným rukopisem umělcovo poprsí. Na druhou stranu tohoto listu si dopsal portrétovaný poznámku „Kresba prítele Maxe Švabinského. M. Aleš . ${ }^{32}$ Podle tohoto portrétu byla dále vytvořena raznice pro knihaře Jendu Rajmana. Tato skica k Alšovu portrétu bývá rovněž velmi často reprodukována, a tak se s ní mưže čtenář setkat na úplném začátku knihy Mikoláš Aleš mládeži (i s Alšovou poznámkou o autorství Maxe Švabinského) nebo ve Špaličku národních písní a říkadel. ${ }^{33}$ Během portrétování v roce 1908 vznikla ještě jedna kresba. Max Švabinský ji daroval i s věnováním Alšově dceři Maryně: „Maryně Alšové na památku portraitování Mistra Mikoláše Alše věnuje Švabinský 9/3 908. "34

Švabinského portrét Alše dokládá, jak dokonalým portrétistou Švabinský byl. Dokázal zachytit nejen podobu a psychiku portrétovaného, ale dovedl do podobizny promítnout i hlubší a na první pohled možná méně nápadnou linii - v tomto případě jím byl vztah

28 Náklon je dobře patrný také na pomníku v Hořicích (1912-1922) od Františka Duchače-Vyskočila (1886-1927), který se celkově velmi blí̌zí Alšově podobizně od Švabinského z roku 1908.

29 Roman Prahl, Věk umělce. Př́ípad Mikoláše Alše, in: Zdeněk Hojda (ed.) - Marta Ottlová (ed.) Roman Prahl (ed.), Vetché stárí, nebo zralý věk moudrosti? Sborník příspěvkư z 28. ročníku sympozia k problematice 19. století: Plzeň, 29. února-1. března 2008, Praha 2009, s. 33.

30 Např́iklad dopis z roku 1923, v němž Maryna Alšová blahopřeje Švabinskému k jeho padesátým narozeninám: „Vzpomínám s vděčností Vaší lásky k mému zesnulému choti, jehož zpodobnil jste v uměleckém podání tak výstižně, živě a pravdivě, že žije Vaším dílem mezi námi."Viz osobní fond Maxe Švabinského v archivu Národní galerie v Praze.

31 Jedna ročenka na rok 1909 je stejně jako originální kresba (inv. č. MAJMA 2951) uložena v uměleckých sbírkách Památníku národního písemnictví pod inventárním číslem IG 11038.

32 Švabinská - Ševčík - Kuna (pozn. 3), s. 239.

33 Aleš (pozn. 16), s. 4; Mikoláš Aleš, Špaliček národních písní a říkadel, Praha 1939, VII.

34 Švabinská - Ševčík - Kuna (pozn. 3), s. 239. 
Mikoláše Alše k „domovu“. Domov je v portrétu zastoupen hned v několika rovinách domov jako místo žití, k němuž byl postarší Aleš upoután, ale jímž byl zároveň inspirován. Další rovinou je chápání domova coby rodinného zázemí a rodinných kořenů, které výrazně formují každého jedince. Tuto rovinu zde zastupuje portrét matky v kresbě milovaného bratra. Poslední možnou interpretací domova je domovina, česká země a český národ. Tímto chápáním domova je prosycena v podstatě celá Alšova tvorba a jeho osobnost, s touto stylizací ostatně Aleš velmi dobře pracoval. ${ }^{35} \mathrm{Z}$ výše uvedeného se zdá, že se Mikoláš Aleš sám ideově podílel na konceptu svého nejslavnějšího portrétu.

\section{SUMMARY}

\section{Inspiring as well as binding Home in Švabinský's portrait of Mikoláš Aleš}

During his life, Mikoláš Aleš enjoyed the reputation of a cheerful man and a talented draughtsman, whose talent is inextricably linked with Czech folklore, history and love for the Czech nation. To some extent, the artist himself contributed to this "image" by his behaviour in society and the scope of his work. It seems probable that even the composition of the portrait by Max Švabinský, is the result of cooperation between a portraitist and a portraited person. The portrait incorporates seemingly genre details (a portrait of Aleš's mother painted by his brother Jan, a cassette with butterflies, an unfinished drawing) referring to the sources of inspiration and the character of Alešs work. Among other things, it was based on the theme of the Slavic homeland, to which he was led from his childhood. In addition to the theme of home as a homeland, the portrait also illustrates the then ambivalent relationship of Mikolás Aleš to his home. The home, which was also a creative place for him in the form of a studio, has been a somewhat binding place for an aging artist in recent years. At the same time, the imaginative Aleš managed to turn it into a place of inspiration for his work. Švabinskýs portrait of Aleš is thus evidenced of the portraitist's great talent manifested both in terms of form and content - thanks to this, Max Švabinský was able to give a completely plastic evidence of the portrayed person.

\section{VÝBĚROVÁ BIBLIOGRAFIE (ŘAZENO CHRONOLOGICKY)}

Emanuel Svoboda, Jak Mikoláš Aleš žil a tvořil, Praha 1920.

Karel Václav Rais, Ze vzpominek II, Praha 1927.

Karel Špillar, Drobné vzpomínky na Mikuláše Aleše II, Český svět XXIV, 1928, s. 6.

Ela Švabinská, Vzpomínky z mládí, Praha 1960.

Maryna Alšová-Svobodová, U nás doma, Praha 1970.

Ludvík Páleníček, Max Švabinský. Život a dílo na přelomu epoch, Praha 1984.

Roman Prahl, Věk umělce. Př́ípad Mikoláše Alše, in: Zdeněk Hojda (ed.) - Marta Ottlová (ed.) - Roman Prahl (ed.), Vetché stárí, nebo zralý věk moudrosti? Sborník př́spěvků z 28. ročníku sympozia k problematice 19. století: Plzeň, 29. února-1. března 2008, Praha 2009, s. 21-38.

Zuzana Švabinská - Václav Ševčík - Martin Kuna, Max Švabinský. Soupis kresliřského a malírského díla 1879-1916, Kroměříž 2014.

35 Více viz v úvodu citovaná bakalářská práce z roku 2015. 


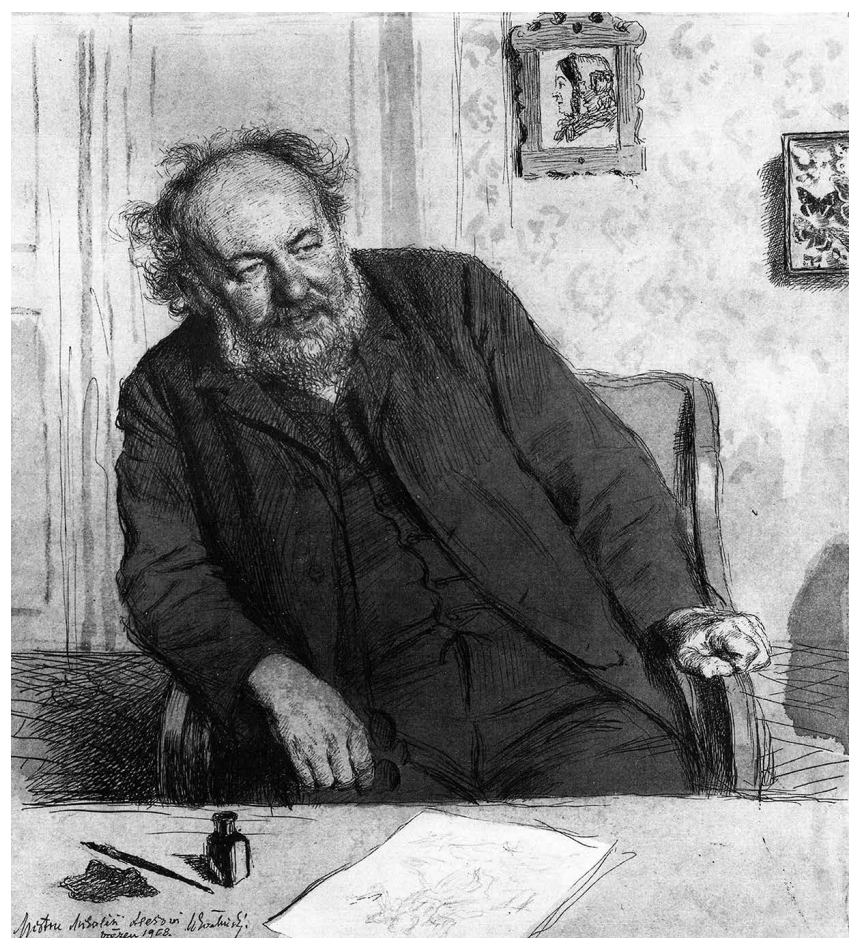

Obrázek 1. Max Švabinský, Portrét Mikoláše Alše, 1908, lavírovaná perokresba, Památník národního písemnictví - umělecké sbírky, inv. č. IG 11038 (heliogravura kresby). Reprodukce z knihy: Zuzana Švabinská - Václav Ševčík - Martin Kuna, Max Švabinský. Soupis kreslírského a malírského díla 1879-1916, Kroměříz 2014, s. 239

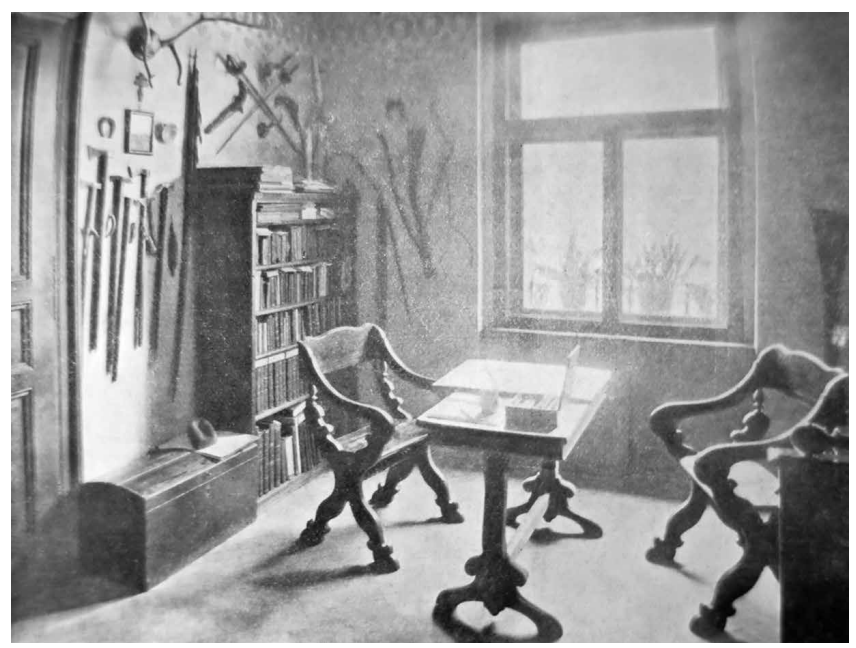

Obrázek 2. Neznámý fotograf, fotografie Alšovy pracovny, 1913. Reprodukce z knihy: Emanuel Svoboda, Jak Mikoláš Alešžil a tvořil, Praha 1920, nepaginováno 

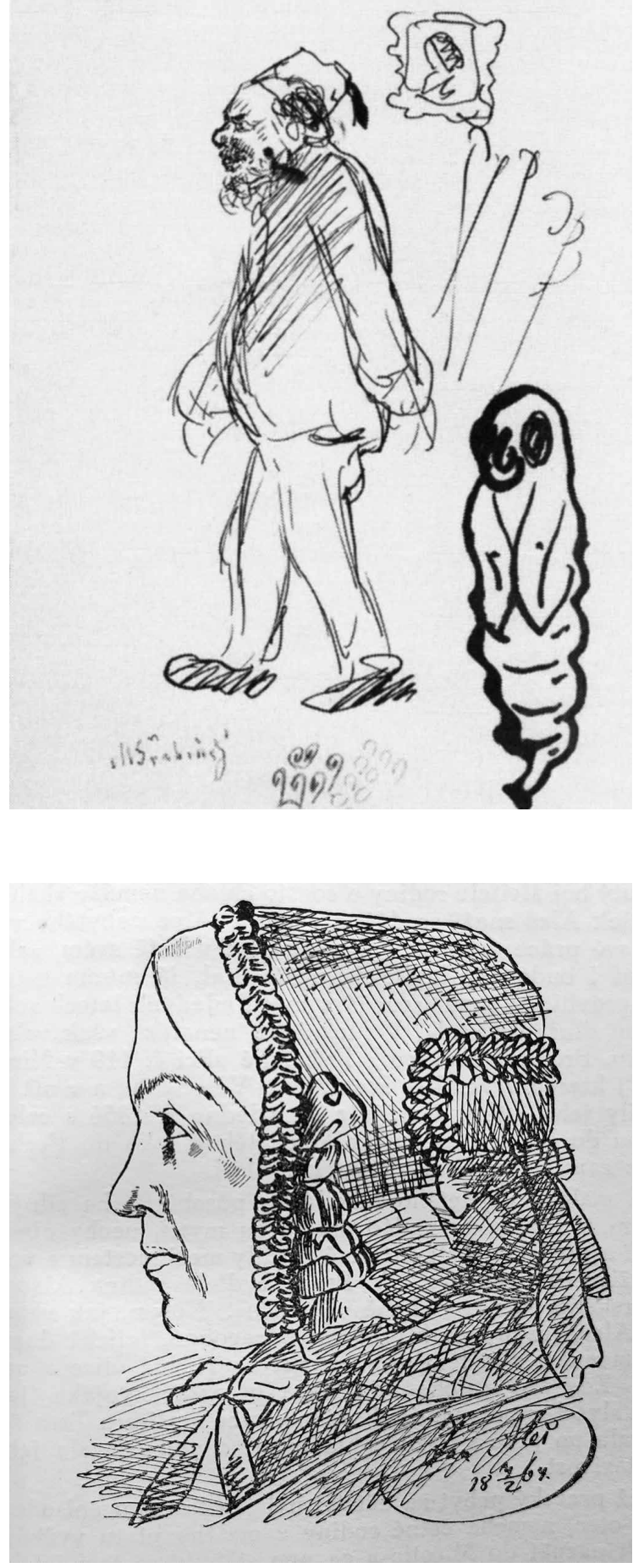

Obrázek 3. Max Švabinský a Mikoláš Aleš, Karikatura Mikoláše Alše a motýlí kukla, perokresba, 1908, soukromý majetek. Reprodukce z knihy: Zuzana Švabinská - Václav Ševčík - Martin Kuna, Max Švabinský. Soupis kreslírského a malírského díla 1879-1916, Kroměříz 2014, s. 240
Obrázek 4. Jan Aleš, Portrét Veroniky Alšové, rozené Fanfulové, perokresba, 1864. Reprodukce z knihy: Emanuel Svoboda, Jak Mikoláš Aleš žil a tvořil, Praha 1920, s. 13 